\title{
Technological Content Knowledge Mahasiswa PGSD Dalam Mengembangkan Multimedia Pembelajaran Matematika
}

\author{
Mukti Sintawati ${ }^{1}$, Fitri Indriani ${ }^{2}$, Ginanjar Abdurrahman³ \\ Universitas Ahmad Dahlan ${ }^{2}$, Universitas Muhammadiyah Jember ${ }^{3}$ \\ mukti.sintawati@pgsd.uad.ac.id
}

\section{Sejarah Artikel}

diterima 07/10/2019

disetujui 17/10/2019

diterbitkan 14/12/2019

\begin{abstract}
The ability to use technology in learning or Technological Content Knowledge (TCK), is one of the skills that must be mastered by teachers in the era of society 5.0. Therefore pre-service teacher must also have the ability to use technology in learning. This study aims to determine TCK pre-service teachers in developing interactive multimedia in mathematics learning. This research is a comparative study. The study population was 300 students of Ahmad Dahlan University Primary School Teacher Education. The research sample was taken randomly as many as 169 students. The research instrument uses the TCK assessment sheet that has been validated by experts. The results showed that the significance level of 5\% TCK for students who developed captivate-assisted learning multimedia was better than students who developed flash-assisted learning multimedia.

Keywords: captivate, flash, technological content knowledge.
\end{abstract}

\begin{abstract}
Abstrak
Kemampuan menggunakan teknologi dalam pembelajaran atau Technological Content Knowledge (TCK) merupakan salah satu kemampuan yang harus dikuasai guru di era society 5.0. Mahasiswa sebagai calon guru juga harus memiliki kemampuan menggunakan teknologi dalam pembelajaran. Penelitian ini bertujuan untuk mengetahui TCK antara mahasiswa yang mengembangkan multimedia pembelajaran matematika berbantuan adobe flash dengan adobe captivate. Penelitian ini merupakan penelitian komparatif. Populasi penelitian adalah 300 mahasiswa Pendidikan Guru Sekolah Dasar Universitas Ahmad Dahlan. Sampel penelitian diambil secara random sebanyak 169 mahasiswa. Instrumen penelitian menggunakan lembar penilaian TCK yang telah di validasi ahli. Hasil penelitian menunjukkan pada taraf signifikansi $5 \%$ TCK mahasiswa yang mengembangkan multimedia pembelajaran berbantuan adobe captivate lebih baik dibandingkan mahasiswa yang mengembangkan multimedia pembelajaran berbantuan adobe flash.

Kata kunci: captivate, flash, technological content knowledge.
\end{abstract}




\section{PENDAHULUAN}

Salah satu penentu keberhasilan pendidikan adalah guru. Untuk itu mempersiapkan guru yang professional seharusnya dilakukan sejak awal, yaitu ketika masih menjadi mahasiswa di Perguruan Tinggi. Mahasiswa calon guru tidak hanya harus menguasai konten atau materi pelajaran tetapi juga harus menguasai model pembelajaran dan penggunaan teknologi dalam pembelajaran. Pada penerapan Kurikulum 2013, guru juga diharapkan menguasai teknologi dalam pembelajaran, serta mampu memanfaatkan/menerapkan teknologi informasi tersebut dalam proses pembelajaran. Hal ini sejalan dengan pemikiran Alayar dkk (2012) bahwa calon guru harus dibekalkan bagaimana metode mengajar, bagaimana menggunakan teknologi informasi dan komputer, memperkuat penguasaan tentang konten keilmuan dan mempelajari bagaimana siswa berpikir dan belajar. Dengan kata lain, untuk meningkatkan kualitas pendidikan, termasuk kualitas pembelajaran matematika di sekolah dasar, harus dimulai dari upaya untuk meningkatkan kualitas persiapan calon guru di perguruan tinggi.

Untuk memahami proses yang terjadi dalam suatu kegiatan pembelajaran dan memahami bagaimana pengaruh pengetahuan guru dalam suatu kegiatan pembelajaran, Shulman (1986) mengusulkan suatu kerangka kerja (framework) pengetahuan guru yang dikenal dengan istilah Pedagogical Content Knowledge (PCK). Menurut Shulman (1987), PCK merupakan gabungan antara pengetahuan tentang muatan materi atau content knowledge (CK) dengan pengetahuan tentang pedagogi atau pedagogical knowledge (PK). PCK adalah gagasan yang muncul dari keyakinan bahwa mengajar membutuhkan lebih dari sekedar memberikan materi atau muatan subjek kepada siswa dan siswa belajar tidak hanya sekedar menyerap informasi tapi bagaimana implementasinya.

PCK mencakup pengetahuan guru tentang inti dari kurikulum, pengajaran, pembelajaran, penilaian, pelaporan, seperti kondisi yang mendorong pembelajaran dan hubungan antara kurikulum, penilaian, dan pedagogi (Lee, Capraro, \& Capraro, 2018). Seorang guru dikatakan mempunyai PCK jika menguasai materi pelajaran, serta mampu menyajikan materi sesuai dengan kebiasaan dan kemampuan siswa (Shing, Saat, \& Loke, 2015). PCK dapat dikembangkan oleh guru. Menurut Loughran dkk (2012) PCK adalah pengetahuan guru yang dikembangkan terus menerus melalui pengalaman tentang bagaimana mengajar materi tertentu dengan cara khusus agar pemahaman siswa dapat tercapai.

Berdasarkan gagasan Shulman tentang PCK, Mishra \& Koehler (2006) telah menambahkan aspek teknologi ke dalam PCK, dengan istilah TPACK (tecnological pedagogical and content knowledge). Menurut Mishra \& Koehler (2006), TPACK adalah kerangka kerja yang mencoba memahami hubungan antara pengetahuan tentang pengajaran (pedagogical knowledge), materi pelajaran (content knowledge), dan penggunaan teknologi (tecnological knowledge). TPACK terdiri dari 7 komponen, 3 komponen utama dan 4 komponen merupakan interaksi dari 3 komponen utama (Yan, Chai, \& So, 
2018). Tiga komponen utama tersebut yaitu technological knowledge (TK), pedagogical knowledge (PK), dan content knowledge (CK).

TK merupakan pengetahuan calon guru tentang apa dan bagaimana teknologi dapat digunakan untuk pembelajaran. PK merupakan pengetahuan tentang karakteristik siswa, pengembangan rencana pembelajaran dan evaluasi hasil belajar, dan apa saja metode/model/strategi pembelajaran yang dapat digunakan dalam pembelajaran. Sedangkan CK meliputi pengetahuan tentang materi pelajaran.

Empat komponen interaksi dari TPACK yaitu technological pedagogical knowledge (TPK), technological content knowledge (TCK), pedagogical content knowledge (PCK), dan technological pedagogical content knowledge (TPACK).

TCK adalah bagaimana guru dapat menggambarkan konten (materi) dengan cara yang berbeda dengan teknologi yang sebelumnya tidak mungkin dilakukan (Guerra, Moreira, \& Vieira, 2017). PCK merupakan ketepatan guru dalam memilih pendekatan atau strategi yang tepat dalam materi tertentu dan sesuai dengan karakter siswa, karena tidak semua strategi cocok digunakan di semua materi. TPK merupakan kemampuan calon guru dalam memilih dan memanfaatkan teknologi yang tepat untuk mendukung penerapan berbagai perangkat pembelajaran yang digunakan.

TPACK merupakan kemampuan guru dalam menyelenggarakan pembelajaran dengan mengintegrasikan strategi pembelajaran dan teknologi. Hal inilah yang membedakan kedalaman penguasaan kompetensi bagi setiap guru mata pelajaran. TPACK merupakan optimalisasi TK yang digunakan dalam pembelajaran untuk mengintegrasikan $\mathrm{CK}, \mathrm{PK}$, dan PCK menjadi satu kesatuan yang utuh yang dapat menghasilkan proses pembelajaran yang efektif, efisien dan lebih menarik

Dalam TPACK, pengetahuan guru untuk mengintegrasikan teknologi dalam pembelajaran membuat pembelajaran menjadi efektif dan efisien. Integrasi teknologi dianggap sebagai komponen pengajaran yang terkait erat dan termasuk juga dalam PCK (Oyanagi dan Satake, 2016).

Perkembangan teknologi yang cepat pada abad 21 ini menjadikan tantangan bagi dunia pendidikan untuk mengembangkan dan menemukan alat yang menambah efisiensi dan nilai bagi proses pembelajaran. Teknologi memiliki pengaruh yang kuat di sekolah sebagai alat yang dapat mengubah cara subjek diajarkan dalam proses pembelajaran, dan pengajaran yang baik mengharuskan bagi guru dan siswa untuk menggunakan teknologi dalam mengumpulkan, mengatur, dan mengevaluasi informasi untuk memecahkan masalah (Srisaswadi, 2012). Mengintegrasikan teknologi ke dalam pengajaran dan pembelajaran di kelas terus menjadi tugas yang menantang bagi banyak guru maupun calon guru. Namun menurut Chai dkk (2013) banyak guru merasa tidak siap untuk penggunaan teknologi terutama teknologi berbasis computer untuk digunakan dalam pembelajaran.

Program studi Pendidikan Guru Sekolah Dasar Universitas Ahmad Dahlan (PGSD UAD) merupakan salah satu perguruan tinggi yang mempersiapkan mahasiswanya untuk 
menjadi guru SD yang profesional. Salah satu yang dipersiapkan adalah kemampuan mahasiswa di bidang teknologi pembelajaran. Mahasiswa PGSD UAD dibekali untuk mempersiapkan pembelajaran menggunakan macromedia flash dan macromedia captivate. Kedua aplikasi tersebut diajarkan

untuk mengembangkan TCK mahasiswa. Berdasarkan uraian tersebut Tujuan dari penelitian ini adalah mendeskripsikan perbandingan tingkat TCK antara mahasiswa yang mengembangkan multimedia pembelajaran matematika berbasis macromedia flash dengan yang mengembangkan multimedia pembelajaran matematika berbasis macromedia captivate. TCK yang akan dinilai terdiri dari tiga aspek yaitu TK, CK, dan TCK. Hasil penelitian yang diperoleh dapat digunakan sebagai bahan evaluasi terkait proses pembelajaran dan evaluasi kurikulum yang ada di PGSD khususnya, atau dapat memberi masukan untuk perbaikan program pendidikan dan pelatihan profesi guru. Hasil perbandingan TCK juga diharapkan menyediakan informasi terkait kemampuan mahasiswa yang sudah unggul, atau sebaliknya aspek kemampuan mahasiswa yang masih memerlukan perhatian untuk dilakukan perbaikan dan peningkatan.

\section{METODOLOGI}

Jenis penelitian ini adalah deskriptif komparatif yang bertujuan untuk membandingkan Technology Content Knowledge (TCK) antara mahasiswa yang mengembangkan multimedia pembelajaran matematika berbasis adobe flash dengan adobe captivate.

Populasi penelitian adalah mahasiswa Pendidikan Guru Sekolah Dasar Universitas Ahmad Dahlan (PGSD UAD) semester 6 tahun ajaran 2018/2019 yang berjumlah 300 mahasiswa. Sampel penelitian diambil secara random sebanyak 169 mahasiswa berdasarkan ukuran sampel dari tabel krecjie (Krecjie, 1970: 608). Seratus enam puluh sembilan mahasiswa tersebut terdiri dari 85 mahasiswa yang mengembangkan multimedia pembelajaran matematika berbasis adobe flash dan 84 mahasiswa yang mengembangkan multimedia pembelajaran matematika berbasis adobe captivate.

Data diperoleh dari hasil penilaian TCK berdasarkan pengembangan multimedia pembelajaran matematika yang dikembangkan mahasiswa calon guru SD.

TCK dinilai menggunakan lembar penilaian. Lembar penilaian disusun berdasarkan aspek Technological Content Knowledge (TCK). Kisi - kisi lembar penilaian dijabarkan dalam Tabel 1. 
Tabel 1.

Kisi-kisi lembar penilaian TCK

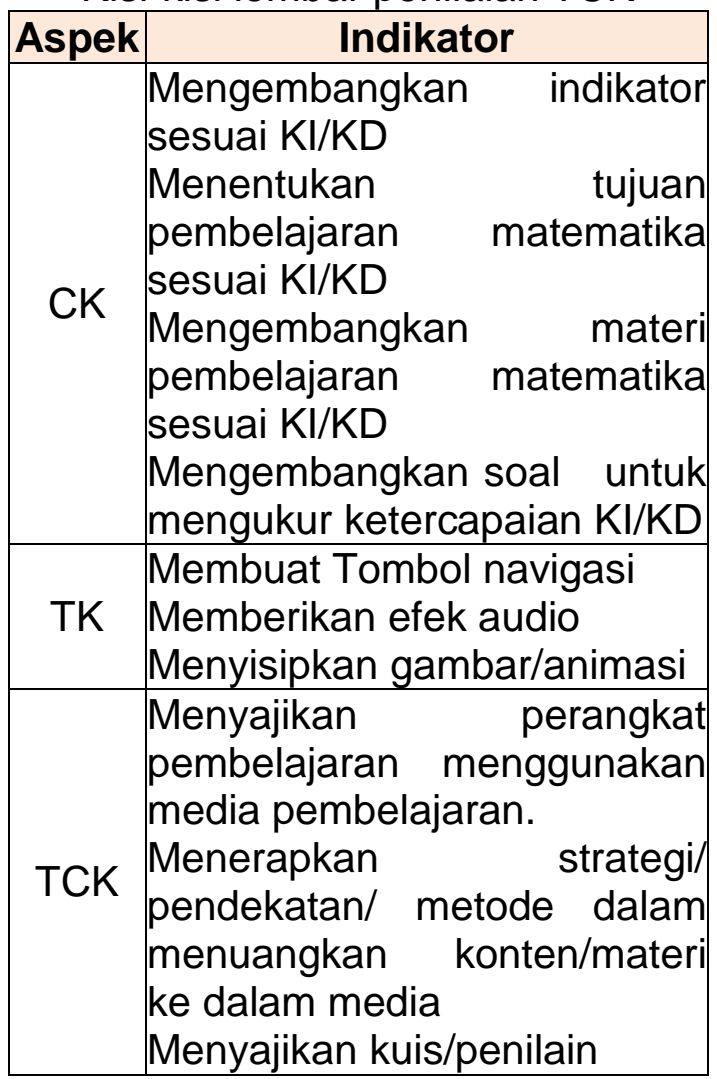

Lembar penilaian terdiri dari 10 sedang, rendah, dan sangat rendah. butir penilaian dengan skala likert Interval dan kriteria TCK disajikan yang memiliki lima alternative pada Tabel 2 (Azwar, 2011: 163). penilaian yaitu sangat tinggi, tinggi,

Tabel 2.

Interval dan kriteria TCK

\begin{tabular}{cc}
\hline Interval & Kriteria \\
\hline$X>4$ & Sangat Tinggi \\
$3,33<X \leq 4$ & Tinggi \\
$2,67<X \leq 3,33$ & Sedang \\
$2<X \leq 2,67$ & Rendah \\
$X \leq 2$ & Sangat Rendah \\
\hline
\end{tabular}

Teknik pengumpulan data matematika yang telah dikembangkan menggunakan teknik non tes yaitu mahasiswa, dan analisis data. menggunakan dokumentasi. Untuk keperluan pengolahan Penelitian dilakukan melalui tahapan data, alternative penilaian pada skala sebagai berikut: menyusun instrumen likert dikonversi menjadi data penilaian TCK, validasi instrumen, uji kuantitatif yaitu "sangat tinggi" $=5$, coba instrumen, pengambilan data "tinggi" $=4$, "sedang" $=3$, "rendah" $=2$, dengan melakukan penilaian terhadap dan "sangat rendah" $=1$.

hasil multimedia pembelajaran 
Teknik analisis data yang akan digunakan untuk menguji hipotesis pada penelitian ini adalah uji $t$ dua sampel independen. Sebelum dilakukan pengujian untuk menjawab rumusan masalah, ada beberapa uji asumsi yang harus dipenuhi terlebih dahulu. Uji asumsi yang harus dipenuhi adalah normalitas dan homogenitas

\section{PEMBAHASAN}

Hasil : Deskripsi data hasil penilaian Technological Content Knowledge (TCK) mahasiswa dalam mengembangkan multimedia pembelajaran matematika disajikan pada Tabel 3.

Dari Tabel 3 dapat diketahui bahwa rata-rata penilaian TCK berdasarkan pengembangan multimedia interaktif berbasis adobe flash adalah 3,28 sedangkan multimedia interaktif berbasis adobe captivate adalah 3,59. Berdasarkan Tabel 1, maka TCK mahasiswa yang mengembangkan multimedia berbasis adobe flash berada pada kriteria sedang, sedangkan TCK mahasiswa yang mengembangkan multimedia berbasis adobe captivate berada pada kriteria tinggi.

Tabel 3.

Deskripsi hasil penilaian TCK

\begin{tabular}{lcc} 
Deskripsi & Flash & Captivate \\
\hline Rata-rata & 3,29 & 3,59 \\
Standar Deviasi & 0,94 & 0,83 \\
Skor maks empiric & 4,05 & 4,4 \\
Skor maks ideal & 5,0 & 5,0 \\
Skor min empiric & 2,75 & 3,1 \\
Skor min ideal & 1,0 & 1,0 \\
\hline
\end{tabular}

Data hasil penilaian TCK rendah, dan sangat rendah. Distribusi mahasiswa dikonversi ke dalam frekuensi skor hasil penilaian TCK kriteria sangat tinggi, tinggi, sedang, disajikan pada Tabel 4.

Tabel 4.

Distribusi frekuensi TCK

\begin{tabular}{lcc}
\hline Kriteria & captivate & flash \\
\cline { 2 - 3 } & $\mathbf{f}$ & $\mathbf{f}$ \\
\hline Sangat Tinggi & 12 & 2 \\
Tinggi & 48 & 30 \\
Sedang & 25 & 52 \\
Rendah & 0 & 0 \\
Sangat Rendah & 0 & 0 \\
\hline
\end{tabular}

TCK mahasiswa dalam

pembelajaran berbasis adobe mengembangkan multimedia 


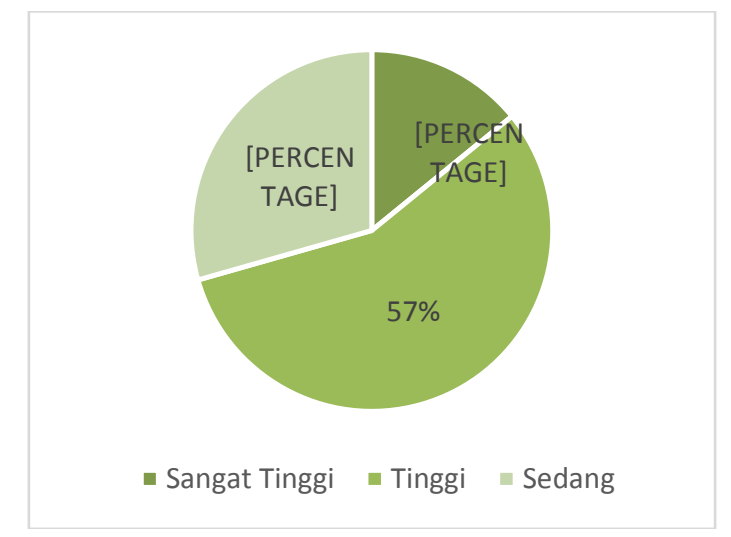

Gambar 1. Persentase TCK mahasiswa yang mengembangkan multimedia pembelajaran matematika berbasis adobe captivate

$\begin{array}{lrl}\text { Persentase skor hasil penilaian } & \text { pembelajaran berbasis adobe flash } \\ \text { TCK } & \text { mahasiswa } & \text { dalam } \\ \text { mengembangkan } & \text { disajikan pada Gambar } 2 .\end{array}$

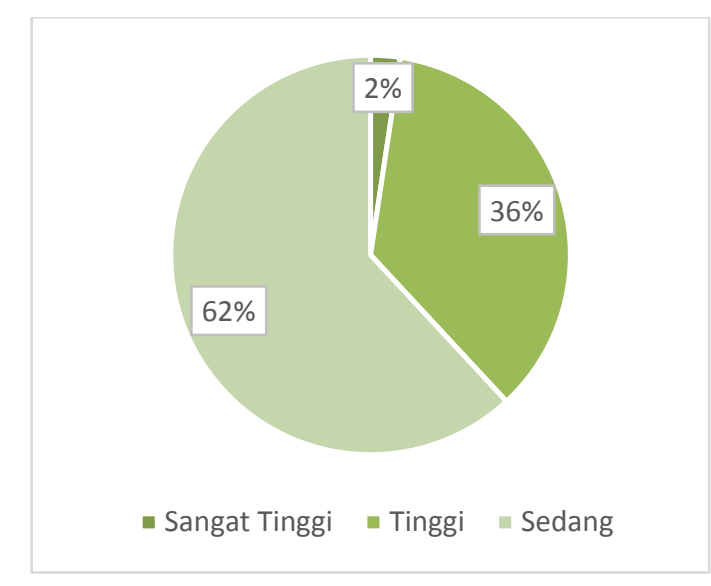

Gambar 2. Persentase TCK mahasiswa yang mengembangkan multimedia pembelajaran berbasis adobe flash

Tabel 3, Gambar 1, dan Gambar 2 diketahui bahwa distribusi frekuensi TCK mahasiswa mengembangkan yang pembelajaran matematika berbasis adobe flash dan adobe captivate berada pada kategori sedang, tinggi, dan sangat tinggi. Di kedua kelas sama-sama tidak ada yang berada di kategori rendah dan sangat rendah.

Rata-rata hasil penilaian TCK mahasiswa berdasarkan aspek-aspek TCK disajikan pada Tabel 5. 
Tabel 5.

Distribusi Frekuensi TCK

\begin{tabular}{lllll}
\hline Kriteria & \multicolumn{2}{c}{ Captivate } & \multicolumn{2}{c}{ Flash } \\
\cline { 2 - 5 } & Rata-rata & kriteria & Rata-rata & kriteria \\
\hline TK & 3,68 & Tinggi & 3,26 & Sedang \\
CK & 3,67 & Tinggi & 3,36 & Tinggi \\
TCK & 3,38 & Tinggi & 3,24 & Sedang \\
\hline
\end{tabular}

Tabel 5 menunjukkan bahwa aspek Technological Knowledge (TK), Content Knowledge (CK), dan Technological Content Knowledge (TCK) mahasiswa yang mengembangkan multimedia pembelajaran berbasis captivate berada pada kategori Tinggi. Aspek Technological Knowledge (TK), dan Technological Content Knowledge (TCK) mahasiswa yang mengembangkan

multimedia pembelajaran berbasis flash berada pada kategori Sedang, sedangkan aspek Content Knowledge (CK) berada pada kategori Tinggi.

Setelah data dideskripsikan, selanjutnya dilakukan uji hipotesis untuk melakukan komparasi. Namun sebelum itu dilakukan uji asumsi normalitas dan homogenitas. Hasil uji normalitas disajikan pada Tabel 6.

Tabel 6.

Hasil Uji Normalitas

\begin{tabular}{lll}
\hline Kelompok & P value & Keterangan \\
\hline Flash & 0,07 & Normal \\
Captivate & 0,12 & Normal \\
\hline
\end{tabular}

Ringkasan hasil SPSS pada hipotesis menggunakan uji tabel 6 menunjukkan bahwa asumsi independent $t$ test. Hasil uji normalitas di kedua kelompok independent $t$ test disajikan pada terpenuhi. Selanjutnya dilakukan uji Tabel 7.

Tabel 7.

Hasil Uji Independent T-Test

\begin{tabular}{lllllll}
\hline & & \multicolumn{2}{l}{$\begin{array}{l}\text { Levene's Test for } \\
\text { Equility of Variances }\end{array}$} & $\begin{array}{l}\text { t-test for } \\
\text { Means }\end{array}$ & Equality of \\
\cline { 3 - 7 } & $\mathrm{F}$ & Sig. & $\mathrm{t}$ & $\mathrm{df}$ & $\begin{array}{c}\text { Sig.(2- } \\
\text { tailed) }\end{array}$ \\
\hline TCK & $\begin{array}{l}\text { Equal variances } \\
\text { assumed }\end{array}$ & 2.648 & .112 & -4.512 & 167 & .000 \\
\hline
\end{tabular}

Hasil uji homogenitas pada Tabel 7 menunjukkan bahwa nilai Sig. lebih dari 0,05, hal ini berarti varians di kedua kelompok homogen. Sehingga asumsi homogenitas terpenuhi. Karena kedua asumsi terpenuhi,
Tabel 7 menunjukkan bahwa hasil uji levene nilai Sig. lebih dari 0,05 , hal ini berarti varians di kedua kelompok homogen. Sehingga asumsi homogenitas terpenuhi. Selanjutnya dari Tabel 7 dapat dilihat bahwa uji independent t-test menunjukkan nilai 
Sig. kurang dari 0,05. Artinya hipotesis ditolak. Hal ini menunjukkan bahwa TCK mahasiswa yang mengembangkan multimedia pembelajaran berbasis adobe

Pembahasan : Hasil dari Tabel 3 menunjukkan bahwa rata-rata TCK mahasiwa yang mengembangkan multimedia pembelajaran berbantuan adobe captivate lebih tinggi dibandingkan dengan adobe flash. Hasil yang sama juga terjadi jika dilihat pada aspek TK dan TCK pada Tabel 5. Hasil CK yang tinggi di kedua kelompok menunjukkan bahwa mahasiswa di kedua kelompok memiliki pengetahuan materi matematika SD yang baik. Pengetahuan ini meliputi kemampuan mengembangkan indikator, menentukan tujuan pembelajaran, mengembangkan materi, mengembangkan soal dan instrumen penilaian pembelajaran sesuai Kompetensi Dasar.

Aspek TK mahasiswa yang mengembangkan multimedia pembelajaran berbantuan adobe captive berada pada kategori tinggi. Hal ini berarti mahasiswa sudah dapat memanfaatkan fitur-fitur pada adobe flash dengan baik, seperti membuat tombol, mememberikan suara, membuat animasi, dan membuat kuis. Sedangkan TK mahasiswa yang mengembangkan multimedia pembelajaran berbantuan adobe flash berada pada kategori sedang. Hal ini captivate lebih baik dibandingkan dengan yang mengembangkan multimedia pembelajaran berbasis adobe flash.

menunjukkan mahasiswa sudah dapat memanfaatkan fitur-fitur yang ada pada adobe flash, namun masih ada mahasiswa yang kesulitan dalam membuat tombol back, dan memberikan audio.

Aspek TCK mahasiswa yang mengembangkan multimedia pembelajaran berbantuan adobe captivate berada pada kategori tinggi. Hal ini menunjukkan bahwa mahasiswa dapat menyajikan materi, memisahkan bagian-bagian materi, membuat kuis interaktif, dan penilaian dalam multimedia pembelajaran berbasis adobe captivate. Selain itu mahasiswa juga dapat menyajikan materi sesuai dengan tahapan pendekatan/model/strategi yang dipilih. Contoh tampilan hasil pengembangan multimedia pembelajaran matematika berbasis captivate yang dikembangkan mahasiswa disajikan pada Gambar 3. Gambar 3 menunjukkan salah satu contoh penyajian materi yang dikembangkan menggunakan adobe captivate. Materi disusun berdasarkan sintaks pendekatan saintifik yaitu mengamati, menanya, mencoba, menalar, dan mengomunikasikan. 


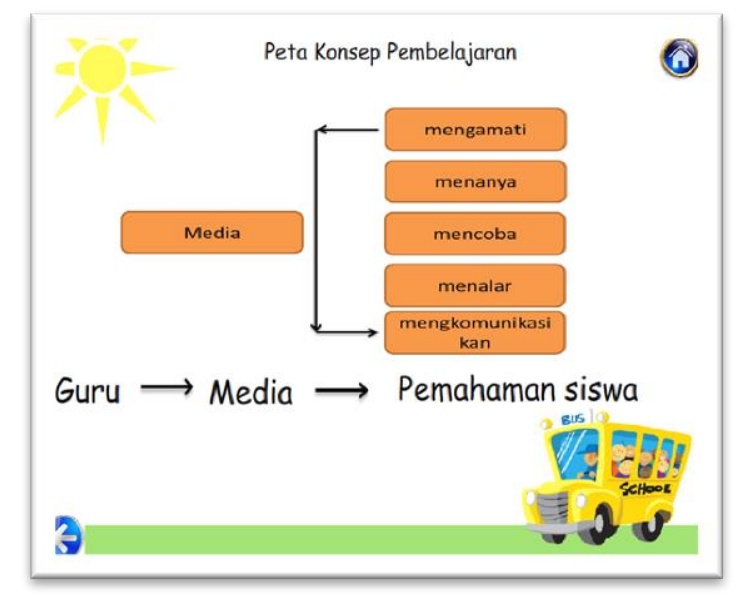

\section{Gambar 3. tampilan multimedia pembelajaran matematika berbasis adobe captivate}

TCK mahasiswa yang mengembangkan multimedia pembelajaran berbantuan adobe flash berada pada kategori sedang. Hal ini menunjukkan mahasiswa sudah dapat menyajikan materi ke dalam multimedia pembelajaran, namun masih ada mahasiswa yang kesulitan dalam membuat kuis interaktif atau menyajikan materi tidak sesuai tahapan yang dipilih. Mahasiswa terkesan hanya memindahkan materi dari buku.

Hasil uji hipotesis pada Tabel 7 juga menunjukkan bahwa TCK mahasiswa yang mengembangkan multimedia pembelajaran berbantuan adobe captivate lebih tinggi dibandingkan dengan adobe flash. Hal ini dikarenakan adobe captivate memang dirancang oleh Adobe Systems Incorporated sebagai software untuk membangun konten pembelajaran digital dengan cepat (Sulianta, 2013: 1). Lebih lanjut Sulianta menjelaskan bahwa adobe captivate memiliki fitur-fitur yang memudahkan bagi guru untuk membuat konten e-learning seperti membuat kuis ataupun game interaktif (Sulianta, 2013: 5). Penggunaan teknologi dalam pembelajaran dapat meningkatkan kesadaran dan pengetahuan guru dalam merencanakan pembelajaran menggunakan aplikasi teknologi dalam proses belajar mengajar (Wulandari, 2019).

Adobe flash merupakan software yang lebih populer digunakan oleh para mahasiswa dan sering diajarkan di perguruan tinggi, namun sebenarnya software ini lebih banyak dipakai oleh para desainer web karena mempunyai kemampuan yang lebih unggul dalam menampilkan multimedia serta hasil proyek yang dapat disimpan dalam berbagai format. Tetapi jika dibandingkan dengan adobe captivate, adobe flash lebih sulit dipelajari (Maliki, 2015: 10). Karena hal inilah kemungkinan hasil multimedia pembelajaran matematika mahasiswa yang dikembangkan berbantuan adobe flash tidak lebih baik dari yang dikembangkan berbantuan adobe captivate. Terutama dalam mengembangkan kuis interaktif. Hal ini juga berdampak pada penilaian TCK yang tidak lebih baik.

Seorang guru matematika tidak cukup menguasai materi, pedagogi, dan teknologi secara terpisah, melainkan harus dapat mengintegrasikan ketiganya untuk 
meningkatkan kualitas pembelajaran (Malubay \& Daguplo, 2018). Hasil penelitian ini menunjukkan bahwa meskipun TCK mahasiswa berada pada kategori sedang dan tinggi, TCK mahasiswa masih harus terus dikembangkan.

\section{SIMPULAN}

Berdasarkan hasil uji hipotesis diperoleh kesimpulan bahwa Technological Content Knowledge mahasiswa yang mengembangkan multimedia berbantuan adobe captivate lebih baik dibandingkan yang berbantuan adobe flash. Hasil TCK mahasiswa yang mengembangkan multimedia berbantuan adobe captivate berada pada kategori tinggi, sedangkan pada hasil TCK mahasiswa yang mengembangkan multimedia berbantuan adobe flash berada pada kategori sedang.
Untuk mengembangkan kemampuan mahasiswa di bidang teknologi, mahasiswa dapat dilatih membuat multimedia pembelajaran menggunakan software adobe flash maupun adobe captivate. Namun untuk lebih memudahkan dalam membuat multimedia pembelajaran matematika, Adobe captivate lebih direkomendasikan karena sudah memuat fitur-fitur pembelajaran seperti kuis, dan equation.

\section{DAFTAR PUSTAKA}

Alayyar, G., Fisser, P., \& Voogt, J. (2012). Developing Technological Pedagogical Content Knowledge in preservice science teachers: Support from blended learning. Australasian journal of educational technology, 28(8), 1298- 1316.

Azwar, S. 2011. Metode Penelitian. Yogyakarta: Pustaka Pelajar.

Chai, C.S., Koh, J. H.L., \& Tsai, C.C. (2013). A Review of Technological Pedagogical Content Knowledge. Educational Technology \& Society, 16 (2), 31-51.

Guerra, C., Moreira, A., \& Vieira, R. (2017). Technological pedagogical content knowledge development: integrating technology with a research teaching perspective. Digital Education, 32: 85-96.

Krejcie, Robert V. dan Daryle W. Morgan. 1970. Ditermining Sample Size or Research Activities. Educational and Psychological Measurment. Vol. 30: 607-610.

Lee, Y., Capraro, R. M., \& Capraro, M. M. (2018). Mathematics teachers' subject matter knowledge and pedagogical content knowledge in problem posing. International electronic journal of mathematics education, 13(2): 75-90. 
Loughran, J., Berry, A., \& Mulhall, P. (2012). Understanding and developing science teacher's pedagogical content knowledge. Rotterdam: Sense Publishers.

Maliki. (2015). Perbandingan hasil belajar siswa antara yang melalui pembelajaran macromedia flash dan macromedia captivate pada konsep system pencernaan di kela VIII smp negeri 3 losari kabupaten Cirebon. Skripsi. lain Syek Nurjati Cirebon.

Malubay, J. \& Daguplo, M. S. (2018). Charactererizing mathematics teachers' technological pedagogical content knowledge. European Journal of Education Studies, 4(1): 199-219.

Mishra, P., \& Koehler, M. J. (2006). Technological pedagogical content knowledge: A framework for teacher knowledge.Teachers College Record, 108(6): 1017-1054.

Oyanagi, W. and Satake, Y. (2016). Capacity Building in Technological Pedagogical Content Knowledge for Preservice Teacher. International Journal for Educational Media and Technology, 10 (1): $33-44$.

Shing, C. L., Saat, R. M, \& Loke, S. H. (2015). The knowledge of teaching-pedagogical content knowledge. The malaysianonline journal of education science, 3(3): 40-55.

Shulman, L. (1987). Knowledge and teaching: foundations of the new reform. Harvard Educational Review, 57(1): 1-22.
Srisaswadi. N. (2012). The Role of TPACK in Physics Classroom: Case Study of Preservice Physics Teachers. Procedia Social and Behavioral Sciences, 46: 3235 - 3234.

Sulianta, Feri. (2013). Aplikasi Interaktif Dengan Adobe Captivate. Jakarta: PT. Elex Media Komputindo.

Yon, Z. M., Chai, C. S., \& So, H., (2018). Creating tools for inquirybased mathematics learning from technological pedagogical content knowledge perspectives: collaborative design approach. Australian journal of educational technology, 34 (4): 57-71.

Wulandari, E. (2019). Teacher's technological pedagogical content knowledge in developing learning materials. Lingua Pedagogia, 1 (1): 29-45 